\title{
Front Matter: Volume 9088
}

, "Front Matter: Volume 9088," Proc. SPIE 9088, Algorithms and Technologies for Multispectral, Hyperspectral, and Ultraspectral Imagery XX, 908801 (8 July 2014); doi: 10.1117/12.2073455

SPIE. Event: SPIE Defense + Security, 2014, Baltimore, MD, United States 


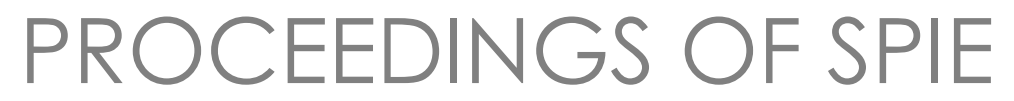

\section{Algorithms and Technologies for Multispectral, Hyperspectral, and Ultraspectral Imagery XX}

Miguel Velez-Reyes

Fred A. Kruse

Editors

5-7 May 2014

Baltimore, Maryland, United States

Sponsored and Published by

SPIE

Volume 9088 
The papers included in this volume were part of the technical conference cited on the cover and title page. Papers were selected and subject to review by the editors and conference program committee. Some conference presentations may not be available for publication. The papers published in these proceedings reflect the work and thoughts of the authors and are published herein as submitted. The publisher is not responsible for the validity of the information or for any outcomes resulting from reliance thereon.

Please use the following format to cite material from this book:

Author(s), "Title of Paper," in Algorithms and Technologies for Multispectral, Hyperspectral, and Ultraspectral Imagery XX, edited by Miguel Velez-Reyes, Fred A. Kruse, Proceedings of SPIE Vol. 9088 (SPIE, Bellingham, WA, 2014) Article CID Number.

ISSN: 0277-786X

ISBN: 9781628410259

Published by

SPIE

P.O. Box 10, Bellingham, Washington 98227-0010 USA

Telephone +1 3606763290 (Pacific Time) · Fax +1 3606471445

SPIE.org

Copyright (C) 2014, Society of Photo-Optical Instrumentation Engineers.

Copying of material in this book for internal or personal use, or for the internal or personal use of specific clients, beyond the fair use provisions granted by the U.S. Copyright Law is authorized by SPIE subject to payment of copying fees. The Transactional Reporting Service base fee for this volume is $\$ 18.00$ per article (or portion thereof), which should be paid directly to the Copyright Clearance Center (CCC), 222 Rosewood Drive, Danvers, MA 01923. Payment may also be made electronically through CCC Online at copyright.com. Other copying for republication, resale, advertising or promotion, or any form of systematic or multiple reproduction of any material in this book is prohibited except with permission in writing from the publisher. The CCC fee code is 0277-786X/14/\$18.00.

Printed in the United States of America.

Publication of record for individual papers is online in the SPIE Digital Library.

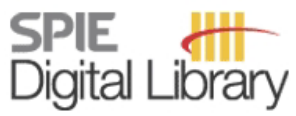

SPIEDigitallibrary.org

Paper Numbering: Proceedings of SPIE follow an e-First publication model, with papers published first online and then in print and on CD-ROM. Papers are published as they are submitted and meet publication criteria. A unique, consistent, permanent citation identifier (CID) number is assigned to each article at the time of the first publication. Utilization of CIDs allows articles to be fully citable as soon as they are published online, and connects the same identifier to all online, print, and electronic versions of the publication. SPIE uses a six-digit CID article numbering system in which:

- The first four digits correspond to the SPIE volume number.

- The last two digits indicate publication order within the volume using a Base 36 numbering

system employing both numerals and letters. These two-number sets start with 00, 01, 02, 03, 04, $05,06,07,08,09,0 A, 0 B \ldots$. 0Z, followed by 10-1Z, 20-2Z, etc.

The CID Number appears on each page of the manuscript. The complete citation is used on the first page, and an abbreviated version on subsequent pages. Numbers in the index correspond to the last two digits of the six-digit CID Number. 


\title{
Contents
}

\author{
ix Conference Committee \\ xi Introduction \\ xiii Dedication: Dr. Sylvia S. Shen
}

\section{SESSION 1 SPECTRAL DATA ANALYSIS METHODOLOGIES I}

908802 Graph-based hyperspectral image segmentation with improved affinity matrix [9088-1]

L. Fan, D. W. Messinger, Rochester Institute of Technology (United States)

908803 Wavelet packet mixing for image fusion and pan-sharpening [9088-2]

W. Czaja, T. Doster, J. M. Murphy, Univ. of Maryland, College Park (United States)

908804 Schroedinger Eigenmaps with nondiagonal potentials for spatial-spectral clustering of hyperspectral imagery [9088-3]

N. D. Cahill, Rochester Institute of Technology (United States); W. Czaja, Univ. of Maryland, College Park (United States); D. W. Messinger, Rochester Institute of Technology

(United States)

$908805 \quad$ Evaluation of a procedure for compressing hyperspectral data [9088-4]

M. E. Winter, E. M. Winter, Technical Research Associates, Inc. (United States)

908806 Effects of preprocessing applied to the compression of ultraspectral images [9088-5]

R. Herrero, M. Cadirola, Ecotronics Ventures, LLC (United States); V. K. Ingle, Northeastern Univ. (United States)

\section{SESSION 2 SPECTRAL SIGNATURE MEASUREMENTS AND APPLICATIONS}

908807 Retrieval of sand density from hyperspectral BRDF [9088-6]

C. M. Bachmann, A. Abelev, U.S. Naval Research Lab. (United States); W. Philpot, Cornell Univ. (United States); K. Z. Doctor, U.S. Naval Research Lab. (United States) and George Mason Univ. (United States); M. J. Montes, R. Fusina, R.-R. Li, U.S. Naval Research Lab. (United States); E. van Roggen, Marine Information Resources Corp. (United States)

908809 The influence of particle size on infrared reflectance spectra [9088-8]

T. L. Myers, C. S. Braver, Y.-F. Su, T. A. Blake, T. J. Johnson, Pacific Northwest National Lab. (United States); R. L. Richardson, U.S. Air Force (United States) 
$9088 \mathrm{OB} \quad$ Hyperspectral target detection using graph theory models and manifold geometry via an adaptive implementation of locally linear embedding [9088-10]

A. K. Ziemann, D. W. Messinger, Rochester Institute of Technology (United States)

$90880 \mathrm{C} \quad$ Enough with the additive target model [9088-11]

A. Schaum, U.S. Naval Research Lab. (United States)

9088 OD Vector tunnel algorithm for hyperspectral target detection [9088-12]

S. Demirci, Turkish Air Force Academy (Turkey); I. Erer, Istanbul Technical Univ. (Turkey);

O. Ersoy, Purdue Univ. (United States)

9088 OE Transductive and matched-pair machine learning for difficult target detection problems [9088-13]

J. Theiler, Los Alamos National Lab. (United States)

\section{SESSION 4 SPECTRAL DATA ANALYSIS METHODOLOGIES II}

9088 OG A comparison of real and simulated airborne multisensor imagery [9088-15]

K. Bloechl, C. De Angelis, M. Gartley, J. Kerekes, Rochester Institute of Technology

(United States); C. E. Nance, Raytheon Intelligence, Information, and Systems (United States)

$9088 \mathrm{OH}$ MODTRAN6: a major upgrade of the MODTRAN radiative transfer code [9088-16]

A. Berk, P. Conforti, R. Kennett, T. Perkins, F. Hawes, Spectral Sciences, Inc. (United States);

J. van den Bosch, Air Force Research Lab. (United States)

9088 ol A spectral climatology for atmospheric compensation [9088-17]

J. H. Powell, R. G. Resmini, George Mason Univ. (United States)

\section{SESSION 5 SPECTRAL METHODOLOGIES AND APPLICATIONS}

9088 OK Multispectral, hyperspectral, and LiDAR remote sensing and geographic information fusion for improved earthquake response [9088-19]

F. A. Kruse, A. M. Kim, S. C. Runyon, S. C. Carlisle, Naval Postgraduate School (United States); C. C. Clasen, Naval Postgraduate School (United States) and National Geospatial-Intelligence Agency (United States); C. H. Esterline, A. Jalobeanu, J. P. Metcalf, Naval Postgraduate School (United States); P. L. Basgall, Naval Postgraduate School (United States) and National Geospatial-Intelligence Agency (United States); D. M. Trask, R. C. Olsen, Naval Postgraduate School (United States)

$9088 \mathrm{OL} \quad$ Estimating radiological background using imaging spectroscopy [9088-20] B. Bernacki, J. E. Schweppe, S. Stave, D. Jordan, J. Kulisek, T. Stewart, C. Seifert, Pacific Northwest National Lab. (United States) 
$9088 \mathrm{OM}$ Subsurface unmixing for benthic habitat mapping using hyperspectral imagery and lidarderived bathymetry [9088-22]

M. C. Torres-Madronero, Instituto Tecnológico Metropolitano de Medellin (Colombia); M. Velez-Reyes, The Univ. of Texas at El Paso (United States); J. A. Goodman, Univ. de Puerto Rico Mayagüez (United States)

9088 ON Parallax mitigation for hyperspectral change detection [9088-23]

K. Vongsy, Air Force Research Lab. (United States) and Air Force Institute of Technology (United States); M. T. Eismann, Air Force Research Lab. (United States); M. J. Mendenhall, Air Force Institute of Technology (United States); V. J. Velten, Air Force Research Lab. (United States)

\section{SESSION 6 SPECTRAL MISSIONS AND DATA COLLECTIONS}

908800 First observations using SPICE hyperspectral dataset [9088-24]

D. Rosario, U.S. Army Research Lab. (United States); J. Romano, U.S. Army Armament Research, Development and Engineering Ctr. (United States); C. Borel, Air Force Institute of Technology (United States)

9088 OP Bobcat 2013: a hyperspectral data collection supporting the development and evaluation of spatial-spectral algorithms [9088-25]

J. Kaufman, M. Celenk, Ohio Univ. (United States); A. K. White, A. D. Stocker, Space Computer Corp. (United States)

$90880 Q \quad$ First results from the hyperspectral imager for climate science (HySICS) [9088-26]

G. Kopp, C. Belting, Z. Castleman, G. Drake, J. Espejo, K. Heverman, B. Lamprecht, Univ. of Colorado at Boulder (United States); J. Lanzi, NASA Wallops Flight Facility (United States): P. Smith, Univ. of Colorado at Boulder (United States); D. Stuchlik, NASA Wallops Flight Facility (United States); B. Vermeer, Univ. of Colorado at Boulder (United States)

\section{SESSION 7 SPECTRAL DATA ANALYSIS METHODOLOGIES III}

9088 OS Multisensor data fusion across time and space [9088-29]

P. V. Villeneuve, S. G. Beaven, Space Computer Corp. (United States); R. Reed, Arnold Engineering Development Ctr. (United States)

9088 OT Simultaneous spectral analysis of multiple video sequence data for LWIR gas plumes [9088-30]

J. Sunu, J.-M. Chang, California State Univ., Long Beach (United States); A. L. Bertozzi, Univ. of California, Los Angeles (United States)

9088 OU Long-wave infrared surface reflectance spectra retrieved from Telops Hyper-Cam imagery [9088-31]

S. M. Adler-Golden, P. Conforti, Spectral Sciences, Inc. (United States); M. Gagnon,

P. Tremblay, M. Chamberland, Telops Inc. (Canada) 
$9088 \mathrm{OV} \quad$ Hyperspectral chemical plume quantification and temperature estimation [9088-32]

S. Niu, Northeastern Univ. (United States); S. E. Golowich, MIT Lincoln Lab. (United States);

V. K. Ingle, Northeastern Univ. (United States); D. G. Manolakis, MIT Lincoln Lab.

(United States)

9088 OW Spectral image fusion using band reduction and contourlets [9088-33]

Y. Choi, E. Sharifahmadian, S. Latifi, Univ. of Nevada, Las Vegas (United States)

9088 0X Determining optimum pixel size for classification [9088-34]

N. M. Rodríguez-Carrión, S. D. Hunt, M. A. Goenaga-Jimenez, Univ. de Puerto Rico

Mayagüez (United States); M. Vélez-Reyez, The Univ. of Texas at El Paso (United States)

\section{SESSION 8 UNMIXING}

$90880 Z$ An analysis of the nonlinear spectral mixing of didymium and soda-lime glass beads using hyperspectral imagery (HSI) microscopy [9088-36]

R. G. Resmini, The MITRE Corp. (United States); R. S. Rand, National Geospatial-Intelligence Agency (United States); D. W. Allen, National Institute of Standards and Technology (United States); C. J. Deloye, The MITRE Corp. (United States)

$908810 \quad$ Novel metrics for object discrimination in overhead real and synthetic color images [9088-37]

P. Duraisamy, A. H. Yousef, K. M. Iftekharuddin, Old Dominion Univ. (United States)

908811 Integrating spatial information in unmixing using the nonnegative matrix factorization [9088-39]

M. A. Goenaga-Jimenez, Univ. de Puerto Rico Mayagüez (United States); M. Vélez-Reyes,

The Univ. of Texas at El Paso (United States)

\section{SESSION 9 DETECTION, IDENTIFICATION, AND QUANTIFICATION II}

908812 Denoising HSI images for standoff target detection [9088-40]

S. Wilson, S. Latifi, Univ. of Nevada, Las Vegas (United States)

908813 Assessment of Schrodinger Eigenmaps for target detection [9088-41]

L. P. Dorado Munoz, D. W. Messinger, Rochester Institute of Technology (United States); W. Czaja, Univ. of Maryland, College Park (United States)

908814 Hyperspectral band selection based on the aggregation of proximity measures for automated target detection [9088-42]

J. E. Ball, D. T. Anderson, S. Samiappan, Mississippi State Univ. (United States)

$908815 \quad$ Effective training set sampling strategy for SVDD anomaly detection in hyperspectral imagery [9088-43]

M. Ergul, N. Sen, O. E. Okman, SDT Space and Defence Technologies (Turkey) 
908817 Effects of optical aberration on chromotomographic reconstruction [9088-45] R. Tervo, Air Force Institute of Technology (United States); M. Hawks, Air Force Institute of Technology (United States) and Oak Ridge Institute for Science and Education (United States); G. Perram, M. Fickus, Air Force Institute of Technology (United States)

908818 Experimental characterization of the quality of image reconstruction from a chromotomographic system [9088-46]

K. J. Dufaud, Air Force Institute of Technology (United States); M. R. Hawks, Air Force Institute of Technology (United States) and Oak Ridge Institute for Science and Education (United States); R. Tervo, Air Force Institute of Technology (United States)

908819 Characterization of a compact 6-band multifunctional camera based on patterned spectral filters in the focal plane [9088-47]

H. E. Torkildsen, H. Hovland, T. Opsahl, T. V. Haavardsholm, S. Nicolas, T. Skauli, Norwegian Defence Research Establishment (Norway)

$90881 \mathrm{~A}$ Tower testing of a $64 \mathrm{~W}$ shortwave infrared supercontinuum laser for use as a hyperspectral imaging illuminator [9088-48]

J. Meola, A. Absi, Air Force Research Lab. (United States); M. N. Islam, L. M. Peterson, K. Ke, M. J. Freeman, Omni Sciences, Inc. (United States); A. I. Ifaraguerri, Leidos, Inc.

(United States)

\section{POSTER SESSION}

9088 1B Local imaging from global measurements applied to selective-spectral imaging [9088-49]

J. Veras, Lockheed Martin Corp. (United States) and Univ. of Central Florida (United States);

R. Muise, D. Twede, Lockheed Martin Corp. (United States)

9088 1C Proper spectral band adjustment for coloristic feature-based recognition of safety signs [9088-50]

C. Merfort, D. Schneider, M. Boehm, Siegen Univ. (Germany)

9088 1E A color calibration method for spectral image based on radiative transfer mechanism [9088-52]

C. Li, L. Ma, X. Yuan, N. Wang, L. Tang, Academy of Opto-Electronics (China); S. Qiu, NOAA-NESDIS Ctr. for Satellite Application and Research (United States); J. Li, Academy of Opto-Electronics (China) and Univ. of Chinese Academy of Sciences (China)

9088 IF Band selection in hyperspectral imagery using sparse support vector machines [9088-53]

S. Chepushtanova, Colorado State Univ. (United States); C. Gittins, UTC Aerospace Systems (United States); M. Kirby, Colorado State Univ. (United States)

Author Index 
Proc. of SPIE Vol. $9088908801-8$

Downloaded From: https://www.spiedigitallibrary.org/conference-proceedings-of-spie on 25 Apr 2023 Terms of Use: https://www.spiedigitallibrary.org/terms-of-use 


\section{Conference Committee}

Symposium Chair

David A. Whelan, Boeing Defense, Space, and Security

(United States)

Symposium Co-chair

Nils R. Sandell Jr., Strategic Technology Office, DARPA (United States)

Conference Chairs

Miguel Velez-Reyes, The University of Texas at El Paso (United States)

Fred A. Kruse, Naval Postgraduate School (United States)

Conference Program Committee

Gail P. Anderson, Air Force Research Laboratory (United States)

Chein-I Chang, University of Maryland, Baltimore County

(United States)

Eustace L. Dereniak, College of Optical Sciences, The University of

Arizona (United States)

Michael T. Eismann, Air Force Research Laboratory (United States)

Glenn E. Healey, University of California, Irvine (United States)

Jacqueline J. Le Moigne, NASA Goddard Space Flight Center (United States)

David W. Messinger, Rochester Institute of Technology (United States)

Alan P. Schaum, U.S. Naval Research Laboratory (United States)

James P. Theiler, Los Alamos National Laboratory (United States)

Grady Tuell, Georgia Tech Research Institute (United States)

\section{Session Chairs}

1 Spectral Data Analysis Methodologies I

Miguel Velez-Reyes, The University of Texas at El Paso (United States)

2 Spectral Signature Measurements and Applications

Fred A. Kruse, Naval Postgraduate School (United States)

3 Detection, Identification, and Quantification I

David W. Messinger, Rochester Institute of Technology (United States) 
Remembering Dr. Sylvia Shen: A Tribute

Fred A. Kruse, Naval Postgraduate School (United States)

Miguel Velez-Reyes, The University of Texas at El Paso (United States)

4 Spectral Data Analysis Methodologies II

Fred A. Kruse, Naval Postgraduate School (United States)

5 Spectral Methodologies and Applications

Michael T. Eismann, Air Force Research Laboratory (United States)

6 Spectral Missions and Data Collections

Miguel Velez-Reyes, The University of Texas at El Paso (United States)

7 Spectral Data Analysis Methodologies III

Miguel Velez-Reyes, The University of Texas at El Paso (United States)

$8 \quad$ Unmixing

David W. Messinger, Rochester Institute of Technology (United States)

9 Detection, Identification, and Quantification II

James P. Theiler, Los Alamos National Laboratory (United States)

10 Spectral Sensor Development and Characterization

Shawn D. Hunt, Universidad de Puerto Rico Mayagüez (United States) 


\section{Introduction}

This year marks the twentieth edition of the SPIE conference on Algorithms and Technologies for Multispectral, Hyperspectral, and Ultraspectral Imagery. This is a very important milestone for our community. The field of multi/hyper/ultraspectral imaging has grown enormously over the past 25 years and this conference has been one of its most important forums since 1994. This year, celebration is a bittersweet one as Dr. Sylvia S. Shen, the conference chair from 1997 to 2013, passed away after a long battle with cancer. There is no doubt that Sylvia's leadership and commitment made this conference what it is today.

The conference was established in 1994 with Dr. E. Evan Iverson from SAIC as chair. He chaired the conference until 1997. From 1998 to 2001, the conference was co-chaired by Dr. Michael R. Descour from the University of Arizona, and from 2002 to 2013 by Dr. Paul E. Lewis from NGA. The 20 conference proceedings volumes include over 1,100 papers. Under Sylvia's and Paul's leadership, the conference experienced enormous growth. To both of them, our deepest thanks.

This year's conference included 51 papers organized in 10 oral sessions and one poster session over two and a half days. A special session was held on Tuesday morning to remember Sylvia and celebrate the conference's 20th edition. Dr. Paul E. Lewis gave a heartfelt presentation summarizing Sylvia's life, leadership, and contributions to the field.

As we move forward looking to the next 20 years, it is the responsibility of those who follow Sylvia's foot steps to continue her legacy and keep this forum a vibrant and relevant one.

Miguel Velez-Reyes Fred A. Kruse 
Proc. of SPIE Vol. $9088908801-12$

Downloaded From: https://www.spiedigitallibrary.org/conference-proceedings-of-spie on 25 Apr 2023 Terms of Use: https://www.spiedigitallibrary.org/terms-of-use 


\section{Dedication: Dr. Sylvia S. Shen}

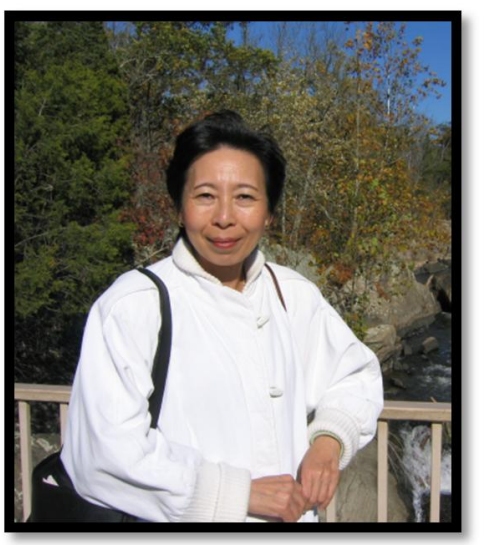

Dr. Sylvia S. Shen, Distinguished Scientist at The Aerospace Corporation and an SPIE Fellow, passed away 13 September 2013, after a six-year battle with cancer.

Shen was the long-time chair for both the Algorithms and Technologies for Multispectral, Hyperspectral, and Ultraspectral Imagery (SPIE Defense, Security, and Sensing) and Imaging Spectrometry (SPIE Optics and Photonics) conferences.

"Dr. Shen's presence and contributions provided important focus for the exchange and evolution of ideas and technology by the community of researchers in the field of spectral remote sensing," said colleague and co-chair Paul Lewis, "Through her committee service and study contributions to the NASA Landsat Program, as a technical consultant to the Department of Energy Multispectral Thermal Imager Satellite Program and as a journal reviewer for SPIE and IEEE."

"Sylvia was one of the smartest and most capable people I have ever known," Lewis said. "I am extremely fortunate to have had the privilege of working with her. Within her petite body dwelled a kind, determined, and noble spirit. Her friendship, teachings, courage of conviction, fortitude and intellect have enriched my life, as well as the lives of other friends and colleagues. The remote sensing community has lost a pioneer in the field of spectral remote sensing."

"Her contributions to the collaborative efforts of the National GeospatialIntelligence Agency and the Environmental Protection Agency to evolve the Airborne Spectral Photometric Environmental Collection Technology (ASPECT) Program have been essential to its decade of airborne emergency response successes," Lewis said. "As a member of the ASPECT Team, Shen deployed, analyzed, and developed state-of-the-art spectral infrared analytical and imagery situational awareness products. These products were deemed essential by first responders and Joint Operation Center personnel since 2003 for mitigation of disasters ranging from Hurricane Katrina to the Deepwater Horizon Oil Spill."

Sylvia will be sorely missed by her friends and colleagues and the scientific community. The two SPIE Conferences she fostered continue to flourish, and along with their long history of scientific contributions, stand as her legacy. 
Proc. of SPIE Vol. $9088908801-14$

Downloaded From: https://www.spiedigitallibrary.org/conference-proceedings-of-spie on 25 Apr 2023 Terms of Use: https://www.spiedigitallibrary.org/terms-of-use 